\title{
De kan hverken ryge eller rejse: Rygeforbuddet i danske fængsler ${ }^{1}$
}

\author{
Af Linda Kjoer Minke, professor MSO, Syddansk Universitet \\ og Ayo Noesborg-Andersen, lektor, Syddansk Universitet
}

\begin{abstract}
In 2017, a smoking ban was introduced in Danish prisons and detention centers. In some of these institutions, inmates are locked in for up to 23 hours per day. The only time inmates can smoke are when staff accompanies them outside to smoke. The smoking ban was instituted to avoid exposing staff and fellow inmates to passive smoking. If a prisoner violates the smoking ban, a disciplinary punishment is imposed. The punishment is up to five days in a penalty cell (solitary confinement).

This article discusses whether the smoking ban interferes with the basic human rights of prisoners as expressed by the European Convention on Human Rights (ECHR). The smoking ban in Danish prisons is then compared to the rules governing residential homes in order to examine whether it violates the principle of equal treatment. Finally, the article discusses whether the penalty for violating the smoking ban is proportional to the purpose of the ban on smoking. The article concludes that a prisoner's right to smoke in his or her cell is probably not covered by Article 3 of the ECHR, but rather by Article 8. This is because the smoking ban appears to be neither proportional nor necessary since the previous set of rules - where prisoners were allowed to smoke in their cells, but not allowed to smoke in the common areas of the prison-served the same purpose, but far less intrusively. In addition, the smoking ban likely constitutes discrimination against inmates, cf. ECHR Article 14 in conjunction with Article 8, as residents of residential homes can smoke in their accommodations.
\end{abstract}

\section{Key-words}

Smoking ban law, prison, Human rights, disciplinary punishment

Rygeforbud i fængsler, fængsler, indsatte, menneskerettigheder, disciplinærstraf

1. Title in English: They can neither smoke nor leave: the smoking ban in Danish prisons. 


\section{Indledning}

I 2007 blev lov om røgfri miljøer vedtaget i Danmark (rygeloven). Loven bestemte, at personer som færdes og opholder sig indendørs på arbejdspladser, skoler, uddannelsessteder, offentlige institutioner og restauranter har et retskrav på ikke at blive udsat for passiv rygning (Lov nr. 512, 2007). Ifølge lovens $\S 14$ forholdt det sig sådan, at beboere på plejehjem, døgninstitutioner, botilbud og i fængsler selv måtte bestemme, om der måtte ryges $\mathrm{i}$ deres bolig. Beboeren/den indsatte kunne dog pålægges ikke at ryge, når personalet opholdte sig i rummet. På trods af denne mulighed har Fængselsforbundet, der organiserer fængselsbetjentene, igennem en årrække påpeget problemet ved, at fængselsbetjente risikerer at blive udsat for passiv rygning med risiko for pådragelse af helbredsmæssige problemer under udførelsen af deres arbejdsopgaver i indsattes opholdsrum/celle. Fængselsforbundet gennemførte således i 2015 en rundspørge blandt Kriminalforsorgens arbejdsmiljørepræsentanter. Af de der besvarede rundspørgen $(n=41)$ svarede syv ud af 10, at de vurderede, at landets fængselsbetjente blev generet af røg i arbejdstiden (Westfall, 2015; Justitsministeriet 2016c).

Ud over, at cellen er en arbejdsplads for fængselsbetjente, tjener den som den indsattes hjem og bolig, imens vedkommende afsoner sin fængselsstraf. For indsatte griber et rygeforbud således ind i deres ret til at bestemme, om der må ryges tobak i deres eget hjem. I lukkede fængsler og arresthuse er rygeforbuddet særligt indgribende, eftersom indsatte kan være låst inde i deres celle i op til 23 timer i døgnet. Disse forhold kendetegner indsatte i fængsler og arresthuse, der af ordens- og sikkerhedsmæssige overvejelser er underlagt isolation disciplinært, samt varetægtsfængslede, der jf. retsplejelovens $\S 770$ a. er underlagt isolation, af hensyn til at modvirke at arrestanten vanskeliggør forfølgningen i sagen ved at påvirke andre.

Den generelle personalemangel i Kriminalforsorgen har desuden medført, at indsatte i lukkede fængsler og arresthuse som forsøgsordning i 2018 er blevet låst inde i deres celle i 12 timer i døgnet (Fængselsforbundet 2018). Forsøgsordningen er efterfølgende udvidet til at omfatte flere lukkede fængsler og arresthuse (Kyed, 2019). Det betyder med andre ord, at en anseelig gruppe indsatte er låst inde $\mathrm{i}$ deres celle $\mathrm{i}$ adskillige timer $\mathrm{i}$ døgnet uden mulighed for at ryge, når de har behov for dette.

Det følger af straffuldbyrdelseslovens $\S 43$, stk. 3, at indsatte har ret til dagligt at tilbringe mindst en time i fri luft, hvor de i princippet kan ryge frit. Adgang til fri luft kan dog nægtes, hvis det er uforeneligt med fængslets sikkerhedsmæssige hensyn. Det vil sige, at det ikke er et ufravigeligt retskrav for indsatte at blive lukket ud dagligt for at ryge. Den indsatte må således tilkalde personalet, i for- 
håbning om dels at de sikkerhedsmæssige hensyn tillader det, dels at personalet har tid og mulighed for at følge den indsatte til et udendørsområde i fængslet, hvor det er tilladt at ryge. Dette kan bedst karakteriseres som, at de indsatte skal have tilladelse af personalet til at ryge, hver eneste gang de har lyst til at ryge en cigaret.

Den 26. oktober 2016 fremsatte den daværende danske justitsminister, Søren Pind, et lovforslag om en udvidelse af rygeforbuddet i Kriminalforsorgens institutioner m.v. Af den kommenterede høringsoversigt fremgår det, at flere høringsberettigede udtrykte bekymring for, at en udvidelse af rygeforbuddet kunne medvirke til en konfliktoptrapning i fængslerne. Desuden udtrykte de høringsberettigede, at sanktioneringen af rygeforbuddet ikke ville stå i et rimeligt forhold til overtrædelsen. Endelig udtrykte DIGNITY - Dansk Institut Mod Tortur samt Institut for Menneskerettigheder, at det indendørs rygeforbud kan udgøre en krænkelse af Den Europæiske Menneskerettighedskonventions (EMRK) artikel 8, stk. 1, om retten til bl.a. privatliv. Justitsministeriet vurderer imidlertid, at indgrebet kan retfærdiggøres i medfør af artikel 8, stk. 2, idet et fuldstændigt indendørs rygeforbud i Kriminalforsorgens institutioner varetager et tungtvejende hensyn til at forebygge sundhedsskadelige virkninger af passiv rygning (Justitsministeriet 2016b).

Lovforslaget blev vedtaget af folketinget i december 2016 med virkning fra den 1. april 2017. Lovændringen omfattede henholdsvis, at $\S 14$ i rygeloven blev ophævet, så indsatte i danske fængsler ikke længere kan bestemme, om der må ryges i deres opholdsrum (cellen). Lovændringen omfattede desuden, at det blev muligt at straffe indsatte disciplinært for overtrædelse af rygelovens regler (Lov nr. 1726, 2016).

Omdrejningspunktet for nærværende artikel er at besvare spørgsmålet, hvorvidt henholdsvis tilladelse til rygning i cellen og et rygeforbud griber ind $i$ indsattes grundlæggende menneskerettigheder, som det er udtrykt i Den Europæiske Menneskerettighedskonvention (EMRK). Spørgsmålet er også, om sanktionerne for overtrædelse af rygeforbuddet i Kriminalforsorgens institutioner er proportionale i forhold til hensigten med rygeforbuddet. Endelig er spørgsmålet, om rygeforbuddet i den indsattes celle strider mod princippet om ligebehandling, hvis andre sammenlignelige grupper har ret til at ryge i deres opholdsrum.

Ganske kort kan det nævnes, at der i Danmark anno 2019 er 13 fængsler (seks lukkede og syv åbne), der omfatter omtrent 2000 afsoningspladser. Derudover findes der 34 arresthuse, Københavns Fængsler, og to arrestafdelinger i fængslerne, der omfatter ca. 1500 arrestpladser (Folketingets Ombudsmand 2019). I perioden 2016-2018 er antallet af indsatte (det gennemsnitlige belæg) steget fra 3.421 
indsatte til 3.738. Antallet af fængselsbetjente er i samme periode faldet fra 2.372 til 2.284 (Direktoratet for Kriminalforsorgen, 2019a:3).

\section{Metodiske overvejelser}

Problemstillingen besvares med anvendelse af den retsdogmatiske metode, hvor formålet er at beskrive gældende ret og retstilstanden, som den er (Blume, 2016). Danske indsattes juridiske status med hensyn til rygning er omfattet af henholdsvis national lovgivning og international ret. Det vil sige, at rygeloven og straffuldbyrdelsesloven med dertilhørende bekendtgørelser og vejledninger samt lokale fængselsregler og retningslinjer i forhold til forvaltningen af rygeforbuddet er inddraget. International ret omfatter den europæiske menneskerettighedslovgivning og praksis i form af domme, der er afsagt af Den Europæiske Menneskerettighedsdomstol (EMD). I den henseende afgrænses EMRK artikel 3 (forbud mod tortur), 8 (retten til privatliv) og 14 (forbud mod diskriminering) som centrale. Der er fundet domme ved hjælp af opslag i HUDOC (EMD's database) samt ved hjælp af anden nyere international litteratur på området.

Til belysning af problemstillingen anvendes desuden relevant forskningslitteratur på området. International forskningsbaseret litteratur er fundet i Academic Search Premier Database ved hjælp af søgeordene smoking ban, prisons or jail or correctional or penitentiary. Søgeperioden er afgrænset til 2003-2019. Begyndelsesåret er valgt, eftersom det er tidspunktet for WHO's lancering af en rammeaftale om tobakskontrol. Der er i alt fundet 36 artikler, heraf er de 17 frasorteret på grund af et ensidigt fokus på enten indeklima eller helbred. Andre $(n=6)$ er frasorteret, fordi de var kommentarer i medicinske tidsskrifter, imens nogle artikler blev sorteret fra, fordi de alene analyserede forhold i psykiatrien. Alt i alt resulterede søgningen således i seks artikler af relevans. Litteraturen er desuden fundet ved hjælp af henvisninger til anden litteratur, herunder rapporter fra UK og WHO.

Endelig består litteraturen af materiale, der er tilvejebragt ved hjælp af ansøgninger om aktindsigt. Det drejer sig om en rapport fra Arbejdstilsynet og et internt notat, der er udarbejdet af Kriminalforsorgen, om de foreløbige erfaringer med det indendørs rygeforbud i Kriminalforsorgens institutioner.

Indledningsvist vil international viden og praksis i forhold til rygeforbuddet $\mathrm{i}$ fængsler blive gennemgået og diskuteret.

\section{Rygeforbud i et internationalt perspektiv}

Til beskyttelse af befolkningens helbred offentliggjorde WHO i 2003 en rammeaftale om tobakskontrol, hvor artikel 8.2 anbefalede, at medlemsstaterne skulle 
tage forholdsregler for at beskytte befolkningen mod at blive udsat for tobaksrøg på arbejdspladser, i offentlige transportmidler og på indendørs offentlige områder (WHO, 2003). I forlængelse af WHO's anbefalinger vedtog en række lande lovgivning vedrørende rygning, men fængslet er som udgangspunkt en vanskelig institution at regulere, eftersom den både tjener som en arbejdsplads og indsattes bolig. Undersøgelser viser desuden, at tobak er det mest udbredte psykoaktive stof blandt indsatte, hvor det angives, at mellem $64 \%$ og 91,8 \% af indsatte globalt set er rygere, og tobaksforbruget stiger ved indsættelse i fængslet (Enggist et al. 2014:138; Kauffman et al., 2011). Sidstnævnte kan forklares med, at tobak bruges som et middel til at håndtere kedsomhed i fængslet, lindre afsavn ved frihedsberøvelsen samt modvirke stress og angst (Butler et al., 2007; Enggist et al. 2014:138; Mackay, 2016; Spaulding et al., 2018).

Argumenterne for et rygeforbud i fængsler er henholdsvis hensynet til beskyttelse af ansattes helbred (Spaulding et al., 2018) og andre indsattes helbred. En brugerundersøgelse blandt danske indsatte $(n=1.993)$ viser i den forbindelse, at $17 \%$. ( $\mathrm{n}=343$ ) svarede, at de i høj eller nogen grad følte sig generet af andres brug af tobaksrøg i fængslet eller arresthuset (Lindstad, 2016: 51). Hovedparten af de indsatte (76\%) svarede imidlertid, at de i ringe grad eller slet ikke følte sig generet (Lindstad, 2016: 51). Forklaringen på, hvorfor hovedparten af indsatte ikke følte sig generet, kan forklares med, at rygning på fællesarealer allerede var forbudt, og at hovedparten af indsatte er placeret i enmandscelle, hvor røgen ikke generer andre end den indsatte selv. Endelig kan en forklaring være, at hovedparten af indsatte er rygere og derfor ikke føler sig generet af tobaksrøg.

Et rygeforbud kan være helt eller delvist, hvor førstnævnte henviser til, at rygning både indendørs og udendørs på fængslets samlede matrikel er forbudt. Et delvist rygeforbud omfatter, at der må ryges på bestemte områder i fængslet, hvilket i de fleste tilfælde omfatter udendørsområder. I delstaten Californien, USA, har der været et totalt rygeforbud siden 2005, og i New Zealand har der været totalt rygeforbud siden 2011. I begge tilfælde omtales ordningen som værende en stor succes, der har foranlediget ganske få problemer. Tilstrækkelige behandlingstilbud, såsom nikotinsubstitutionspræparater $\left(\mathrm{NRT}^{2}\right)$ suppleret med indførelsen af flere aktiviteter i fængsler, forklarer, hvorfor forbuddet anses som en succes (OHRN, 2014:21 f.; Djachenko et al. 2016). På Isle of Man har der siden 2008 været indført et totalt rygeforbud i fængsler. I 2011 besøgte tilsynsmyndig-

2. Nicotine replacement therapy 
heder $\left(\mathrm{HMIP}^{3}\right)$ Isle of Man, og samlet set gav inspektionen anledning til, at HMIP anbefalede at ophæve det totale rygeforbud og at give ind- og ansatte mulighed for at ryge udendørs. Anbefalingen blev ikke imødekommet, men i 2012 udtalte fængselsmyndighederne, at der siden tidspunktet for inspektionen havde været et fald i regelbrud af rygeforbuddet, og at indsatte såvel som ansatte generelt set var tilfredse med det totale rygeforbud (OHRN, 2014:18).

Praksis viser dog, at det er særdeles vanskeligt for fængslerne at håndhæve et totalt rygeforbud. Der er fundet eksempler på, at indsatte eksperimenterer med at tilvirke nikotinrelaterede nydelsesmidler, der i sig selv indebærer sundhedsfare (Puljevic et al., 2018). Desuden er der risiko for, at indsatte reagerer med vrede og frustration, på grund af de begrænsninger som et totalt rygeforbud omfatter. Endelig må personalet bruge forholdsmæssigt megen tid på at sikre en effektiv overholdelse af et totalt rygeforbud. I Quebec-provinsen, Canada, gennemførtes i 2008 et totalt rygeforbud, der dog tre år senere blev ophævet, eftersom der blev oprørslignende tilstande $\mathrm{i}$ et fængsel. Herefter fik indsatte mulighed for at ryge udendørs (OHRN, 2014:14 f.).

I delstaten Victoria, Australien, blev der i 2004 indført et delvist rygeforbud, hvor indsatte alene har lov til at ryge udendørs. I særlige tilfælde, såsom hvis den indsatte lider af mentale problemer, hvis forbuddet konfliktoptrapper, eller hvis den indsatte er isoleret med begrænset mulighed for at komme udendørs, kan fængselsinspektøren tillade indsatte at ryge i deres celle (OHRN, 2014:13). Hvordan reglerne bliver håndhævet, afhænger dermed af de konkrete omstændigheder i den enkelte sag.

Det delvise rygeforbud tyder på at være mest udbredt, men der er store forskelle på, om cellen er omfattet af et rygeforbud, afhængig af om myndighederne primært opfatter cellen som den indsattes private domæne eller som en arbejdsplads. I Tyskland har indsatte mulighed for at ryge både udendørs og i cellen, imens rygning er forbudt i fængslets fællesområder (Enggist, 2014: 142; 187). I UK må indsatte ikke ryge i fængslets fællesarealer, men det er tilladt at ryge i deres egen celle, når de pågældende vel at mærke ikke deler celle med en ikkeryger (OHRN, 2014:7).

I de nordiske lande forholder det sådan, at i Island er rygning ikke tilladt på fængslets fællesområder, imens rygning er tilladt i den indsattes celle (Heilbrigðis- og tryggingamálaráðuneyti, 2007). Tilsvarende ses det i Norge, hvor rygning ikke er tilladt på fængslets fællesarealer, imens cellen defineres som den

3. Her Majesty's Inspectorate of Prisons. 
indsattes bolig, hvor han eller hun indsatte som udgangspunkt har ret til at ryge (LOV-1973-03-09-14; Fantoft, 2011: 58). I de fleste nyetablerede norske fængsler er der imidlertid indført et totalt indendørs rygeforbud, hvor indsatte dog har adgang til altaner, så de kan komme ud for at ryge. I Sverige har der siden 2007 været indført rygeforbud indendørs (Kriminalvårdens föreskrifter och allmänna råd om häkte $\S 24)$. Rygning skal således foregå udendørs på tidspunkter og steder, som Kriminalvården [Kriminalforsorgen] beslutter. Den 10. juli 2019 berettede det svenske nyhedsmedie Västerviks-Tidningen imidlertid, at det svenske fængselssystem overvejer at indføre et totalt rygeforbud i samtlige fængsler og arresthuse. Begrundelserne er, at et sådant indgreb dels følger de samfundsmæssige tendenser, dels sparer ressourcer, idet fængselsbetjente ved eksempelvis Norrtäljeanstalten bruger 72 timer om ugen på at kontrollere indsattes rygeremedier, overvåge rygearealer samt håndtere inventar, der manipuleres af indsatte, så de kan tænde cigaretter (VT, 2019). I Finland er lovgivningen sådan, at rygning ikke er tilladt i fængslets fællesområder, imens det er op til det enkelte fængsels lokale regler at tillade indsatte at ryge i cellen (Vankien asuminen ja perushuolto (19/004/2010). Der er imidlertid planer om fra 2020 at indføre et totalt rygeforbud, der omfatter alle fængsler i Finland (Uutiset, 2018).

Som det er fremgået, er der store internationale forskelle på, hvordan rygeregler både fortolkes og implementeres i fængsler. Det centrale er, om cellen opfattes som den indsattes private domæne eller ej. Modstandere af et rygeforbud i fængsler, herunder indsattes celle, begrunder dette blandt andet med, at indsatte har ret til selv at bestemme, om de vil ryge, at et rygeforbud kan forårsage oprørslignede tilstande i fængslet, og at rygning hjælper indsatte til at overkomme kedsomhed, stress og angst m.v. (Spaulding et al, 2018:82 f.). Tilhængere af et rygeforbud begrunder dette med, at helbredet blandt ansatte og ikkerygende indsatte beskyttes.

I det følgende vil vi se nærmere på sager, hvor indsatte har klaget over, at de ufrivilligt har været udsat for passiv rygning, hvorfor de hævder, at deres menneskerettigheder er blevet krænket under fængselsopholdet.

\section{Ret til ikke at blive udsat for passiv rygning}

Rygeproblematikken kan deles i to problemstillinger: For det første er der den ovennævnte situation, hvor indsatte skal have lov til at ryge, altså retten til aktiv rygning. For det andet kan indsatte, der ikke ryger, ufrivilligt blive udsat for tobaksrøg, hvis der ikke er regler for rygning, og dette kan påvirke deres helbred $\mathrm{i}$ en negativ retning, altså retten til at blive beskyttet mod passiv rygning.

Den Europæiske Menneskerettighedsdomstol (EMD) har så vidt vides aldrig behandlet retten til aktiv rygning, men har i flere tilfælde taget stilling til retten til 
at blive beskyttet mod passiv rygning i fængsler. Sagerne omhandlede artikel 2, 3 og 8 i den Europæiske Menneskerettighedskonvention, som henholdsvis omhandler ret til liv (artikel 2), at ingen må underkastes tortur eller udsættes for umenneskelig eller vanærende behandling eller straf (artikel 3) samt ret til respekt for privatliv og familieliv (artikel 8).

EMD's praksis på området har udviklet sig i løbet af de sidste år, i takt med at samfundets holdning til rygning har ændret sag. De første sager om rygning i fængsler dukkede op i starten af 00'erne, og blev primært ført som sager om krænkelse af artikel 2 og 8. I sagen Aparicio Benito mod Spanien (2006) var sagsøgeren ikkeryger og placeret i egen celle, mens hovedparten af fængslets øvrige cirka 100 indsatte var rygere. Da Aparicio indbragte sagen for EMD, var der ingen røgfrie områder i fængslets fællesområder. Spaniens fængselslovgivning havde ikke nogen bestemmelser om, at indsatte havde ret til at opholde sig i et røgfrit miljø. Aparicios sag blev afvist af flere grunde: Han havde ikke fremlagt dokumentation for sine helbredsproblemer som følge af den passive rygning, og der var ikke en klar konsensus blandt medlemslandene på området. Han fik således ikke medhold i sin klage over, at hans menneskerettigheder jf. artikel 2 og 8 var blevet krænket. Det er dog værd at bemærke, at domstolen medgav, at det at en ikkeryger blev tvunget til at opholde sig sammen med rygere kunne være et indgreb i forhold til artikel 8. Domstolen noterede sig også specifikt, at Spanien havde ret til selv at finde den rette balance imellem rygernes og ikkerygernes rettigheder - underforstået, at begge parter har disse rettigheder.

I sagen Stoine Hristov v. Bulgaria (2008) klagede sagsøger over, at han var tvunget til at dele celle med indsatte, der var rygere, hvorfor han anlagde sag om krænkelse af artikel 3. Domstolen henførte dog klagen under artikel 8, i kendelsen om hvorvidt sagen kunne behandles. Hristov kunne ikke dokumentere, at rygningen faktisk havde påvirket hans helbred, og på tidspunktet for klagen delte han ikke længere celle med rygere. Faktisk havde han allerede i 2002, inden anlæggelsen af sagen, skrevet til fængselsinspektøren og oplyst denne, at han på daværende tidspunkt befandt sig i en ikkerygercelle, modsat hans påstand under sagen om at være anbragt $i$ en rygercelle indtil 2005. Disse to kendsgerninger, sammenholdt med den skønsmargin, som er overladt til medlemslandene i mangel af fælles konsensus, gjorde, at Hristov ikke fik medhold af EMD.

Hvor EMD altså ikke fandt krænkelser af artikel 2 eller 8, er det anderledes, i de sager der påberåber sig artikel 3. Sagen Ostrovar v. Moldova (2005) omhandler en indsat, der var placeret i en celle på $25 \mathrm{~m}^{2}$ sammen med 20 andre indsatte. Fængslets regler forbød rygning i celler, men uagtet dette røg flere indsatte i cellen. Sagsøgeren var diagnosticeret med astma, og på grund af eksponeringen for 
tobaksrøg fik han dagligt flere astmatiske anfald. I tillæg til at sagsøgeren blev udsat for passiv rygning i cellen, blev fængselsforholdene generelt vurderet som »a serious health risk.« Domstolen fandt, at de kumulative virkninger af forholdene i fængslet, herunder manglen på sundhedsbistand, eksponering for cigaretrøg, utilstrækkelig mad, uhumske forhold m.v., gjorde, at der var sket en overtrædelse af artikel 3.

I sagen Florea v. Romania (2010) delte den indsatte celle med mellem 110 og 120 andre indsatte, hvoraf $90 \%$ var rygere. Den indsatte var i flere perioder indlagt på fængslets sygeafdeling, hvor han også var udsat for passiv rygning. Sagsøgeren klagede således især over, at han i knap tre år havde været indespærret sammen med rygere i henholdsvis sin fængselscelle og på fængselshospitalet. Domstolen fandt, at der stadig ikke var konsensus blandt medlemsstaterne i forhold til at beskytte indsatte mod passiv rygning (p. 60), men der var klare nationale regler, der forbød rygning på hospitaler. Samtidig havde de rumænske domstole udviklet en retspraksis, hvorefter indendørsområderne i fængslerne skulle betragtes som offentlige rum, hvor loven forbød rygning (p. 30 og 62). EMD vurderede, at artikel 3 var blevet krænket, primært på grund af overbelægningen, sammenholdt med uhumske forhold og den passive rygning. Derudover havde de rumænske myndigheder ikke udvist hensyn til sagsøgerens sårbarhed og klage, modsat hhv. Aparicio Benito (anbringelse i enmandscelle) og Stoine Hristov (overførsel til ikkerygercelle efter klage) (p. 61-62). Domstolen tog dog ikke separat stilling til, hvorvidt den passive røg havde forværret den indsattes helbred (p. 65). Det er værd at bemærke, at EMD specifikt udtalte, at selv om det er forbundet med gene at være tilbageholdt mod sin vilje - som indsatte i fængsler jo er - betyder dette ikke, at de indsatte mister deres rettigheder. Tværtimod har de indsatte $\mathrm{i}$ visse tilfælde brug for ekstra beskyttelse, både fordi de er særligt sårbare, og fordi statens ansvar for dem er altomfattende (p. 50).

Sagen Elefteriadis v. Romania (2011) omhandlede en livtidsdømt indsat, der under fængselsopholdet blev diagnosticeret med en kronisk lungesygdom. Lægeundersøgelser og rådgivning fra læger dokumenterede, at passiv rygning ville forværre hans lungesygdom. Sagsøgeren klagede således over, at han i løbet af sit fængselsophold i flere situationer havde været udsat for passiv rygning, såsom i forbindelse med transport fra arresten til retten, i ventelokalet til retten og i fængselscellen, som han delte med to indsatte, der begge røg. Domstolen fandt, at der var sket en overtrædelse af artikel 3, idet en stat er forpligtet til at træffe foranstaltninger til beskyttelse af indsatte fra de skadelige virkninger af passiv rygning, når lægeundersøgelser og lægerådgivning dokumenterer, at dette er nødvendigt af sundhedsmæssige årsager. 
I sagen Vasilescu v Belgium (2014) klagede sagsøgeren over, at han i mere end et år havde delt celle med indsatte, der alle var rygere, på trods af hans anmodning om at blive anbragt i en ikkerygercelle. Desuden var fængslet overfyldt, der var ikke senge nok til alle indsatte, og cellen havde ikke adgang til toilet og rindende vand. I dette tilfælde var det overfyldte fængsel ikke i sig selv grundlag nok for at statuere en krænkelse af artikel 3, men på grund af de samlede omstændigheder ved fængselsopholdet, heriblandt den passive rygning, vurderede EMD, at artikel 3 var krænket.

Samlet kan det konkluderes, at passiv rygning i fængsler kan føre til en krænkelse af artikel 3, men alene, hvis der enten er påvist helbredsproblemer i forbindelse med rygningen, eller hvis de samlede omstændigheder ved opholdet kan statuere en krænkelse. Domstolen synes også at lægge vægt på, hvorvidt myndighederne overhovedet viser hensyn eller reagerer på klager. EMD har gentagne gange pointeret, at der ikke eksisterer en fælles konsensus på området, og derfor har medlemslandene en ret stor skønsmargin til selv at vælge, hvorvidt de vil skærme ikkerygere fra passiv rygning. Der er altså ikke for nuværende en pligt til at indføre generelle rygeforbud i fængsler.

Før rygelovgivningen i danske fængsler blev ændret, var det som tidligere nævnt sådan, at indsatte kun måtte ryge indendørs, hvis dette foregik i deres egen celle. Udgangspunktet i Danmark er, at indsatte i lukkede fængsler og arresthuse ikke deler celle med andre, og derfor var passiv rygning ikke et problem for andre indsatte. Den tidligere lovgivning overholdt altså EMRK's artikel 3, i hvert fald hvad angik passiv rygning.

Retten til aktiv rygning findes der som nævnt ikke retspraksis på. Det er derfor usikkert, om EMD vil fastslå, at en sådan ret findes, og at manglende beskyttelse af denne kan karakteriseres som umenneskelig og nedværdigende behandling, som vil føre til et brud på artikel 3. Dette især i betragtning af, at rygningens negative sundhedsmæssige konsekvenser er alment kendte. Men andre artikler fra EMRK kan muligvis gøres gældende. Fordi indsatte, der ryger, har mistet rettigheden til at bestemme, om der må ryges i egen celle, og fordi et rygeforbud også er et indgreb i retten til privatliv i artikel 8, er det værd at undersøge, om dette griber ind i EMRK's artikel 8 om ret til respekt for privatliv og familieliv.

\section{Retten til selv at bestemme, om man vil ryge}

EMRK's artikel 8 beskytter bl.a. retten til privatliv, herunder retten til selvbestemmelse i eget hjem. Rygeforbuddet i danske fængsler gælder alle indendørs arealer, herunder indsattes celle, som indsatte i mange tilfælde opfatter som sit hjem. Om begrebet »hjem« lægger Den Europæiske Menneskerettighedsdomstol 
vægt på, at der skal være tale om en tilstrækkelig og kontinuerlig tilknytning til et bestemt sted, for at det kan forstås som et hjem. Et argument imod den kontinuerlige tilknytning kan være en antagelse om, at opholdet i fængslet er af midlertidig karakter. Det forholder sig dog sådan, at ud af 2145 personer, der fuldbyrdede en fængselsstraf i 2017, afsonede i alt 304 personer en tidsubestemt forvaringsdom eller fængselsstraffe fra 10 år og indtil livstid (Direktoratet for Kriminalforsorgen 2017: 19). I disse tilfælde må cellen opfattes som den pågældendes hjem på tilsvarende vis som et værelse på et andet opholdssted.

Den indsatte har ikke selvbestemmelse over cellen, hvilket kan tale imod, at den er omfattet af definitionen, idet et element af hjemretten er at kunne bestemme, hvem der har adgang til ens hjem, og hvornår de må få adgang (Nielsen, 2011: 62). Selvbestemmelsesretten er dog primært indskrænket på baggrund af bestemmelser, som har til formål at tilgodese ordens- og sikkerhedsmæssige hensyn i fængslet. Dette kan derfor ses som et udslag af statens ret til at gøre indgreb i retten til privatliv, som beskrevet lige nedenfor, og den manglende selvbestemmelsesret bør derfor ikke i sig selv føre til, at cellen ikke kan defineres som indsattes hjem. Det er i den forbindelse værd at bemærke, at EMD i Aparicio v. Spain (se gennemgang af sagen ovenfor) udtalte, at det kunne være et indgreb $i$ henhold til artikel 8, hvis ikke--rygere blev tvunget til at opholde sig sammen med rygere.

Sammenlagt må det altså konkluderes, at cellen kan ligestilles med den indsattes hjem, idet i hvert fald langtidsindsatte har en kontinuerlig tilknytning til denne, og da de indsatte både sover og opbevarer deres personlige ejendele $\mathrm{i}$ cellen, må tilknytningen også siges at være tilstrækkelig - især da mange langtidsindsatte selv karakteriserer cellen som deres hjem.

Staten har som netop nævnt mulighed for at gøre indgreb i EMRK-artikel 8, jf. stk. 2 i samme artikel. Indgrebet skal dog have hjemmel i lov, være nødvendigt $i$ et demokratisk samfund (nødvendighedskravet) og forfølge et anerkendelsesværdigt formål, såsom at beskytte sundheden eller at beskytte andres rettigheder og friheder. Rygeforbuddet i danske fængsler er da også foretaget i overensstemmelse med lov om røgfri miljøer $\S 6$, jf. $\S 4$, og forfølger som udgangspunkt et anerkendelsesværdigt formål med hensyn til at tilgodese sundheden blandt personalet samt øvrige indsatte, der ikke ryger. Hjemmelskravet og formålsbestemmelsen er dermed opfyldt. Tilbage står spørgsmålet om nødvendighed.

Som nævnt var praksis før lovgivningen sådan, at personalet kunne bede indsatte om at lufte ud i cellen, inden de førstnævnte skulle udføre deres arbejdsopgaver. Som det ligeledes er fremgået, forholder det sig sådan, at indsatte i lukkede fængsler og arresthuse som det klare udgangspunkt ikke deler celle med andre. 
Hensynet til personale og andre indsatte blev altså opfyldt med det gamle regelsæt og kan ikke i sig selv retfærdiggøre de nye, strammere regler. Det kan især diskuteres, om hensynet til de ansatte kan retfærdiggøre forbuddet. Her skal især tages i betragtning, at de ansatte jo trods alt frivilligt har valgt deres arbejdsplads, mens de indsatte er blevet dømt af en domstol til ophold i fængslet. Ifølge EMD’s praksis mister indsatte ikke beskyttelsen af deres menneskerettigheder ved at begå en lovovertrædelse, og enhver indskrænkning i deres rettigheder skal derfor overvejes nøje (Hirst v. UK (No. 2):70).

I dette tilfælde er det nok tvivlsomt, om forbuddet opfylder nødvendighedskravet, da det tidligere regelsæt stort set opfyldte samme formål, men var langt mindre indgribende.

Det er desuden sandsynligt, at rygeforbuddet har fremkaldt negative reaktioner blandt indsatte. Af en undersøgelse af vold og trusler mod personalet i Kriminalforsorgens institutioner i perioden 2007-2017 fremgår det, at rygeforbuddet nævnes som en faktor, der kan have skabt grobund for flere konflikter, der endte/kan have endt i vold eller trusler mod personalet (Clausen \& Bien 2018:46). Dette taler imod, at forbuddet opfylder nødvendighedskravet, idet en mindre indgribende løsning med al sandsynlighed ville have medført mindre vold og færre trusler og dermed højnet netop det arbejdsmiljø, som forbuddet skulle gavne.

I forlængelse heraf er det naturligt også at diskutere, om indgrebet er proportionalt, i forhold til den straf som de indsatte ikendes, hvis de overtræder forbuddet.

\section{Er det proportionalt at straffe med isolation, hvis en indsat besidder rogtobak?}

I 2016 medførte en lovændring, at ordlyden af straffuldbyrdelseslovens $\S 67 \mathrm{blev}$ ændret fra kan til skal, så en indsat i bestemmelsens nævnte tilfælde altid skal ikendes disciplinærstraf. Ved indførelsen af lov om udvidelse af rygeforbuddet $\mathrm{i}$ Kriminalforsorgens institutioner m.v. fik straffuldbyrdelsesloven $\S 67$, stk. 1 tilføjet nr. 6, hvor ordlyden er, at en indsat af kriminalforsorgsområdet skal ikendes disciplinærstraf ved overtrædelse af regler eller anvisninger, der gælder for rygning $\mathrm{i}$ institutionen (Lov nr. 641 af 8. juni 2016; Lov nr. 1726 af 27. december 2016).

For at imødekomme en effektiv overholdelse af rygeloven i danske fængsler og arresthuse er reglerne for, hvad indsatte må opbevare i sin celle (genstandsbekendtgørelsen), blevet ændret, så indsatte ikke længere må være i besiddelse af rygerelaterede genstande, herunder tændstikker, lightere og lignende tændredskaber m.v. i deres celle (Bekendtgørelse nr. 1610, 2018). Sådanne rygerelaterede 
genstande opbevares nu i et aflåst skab uden for den indsattes celle og udleveres af personalet, når den indsatte skal ud for at ryge.

Hvis indsatte overtræder rygeloven og/eller overtræder de regler, der gælder i genstandsbekendtgørelsen, skal de jf. straffuldbyrdelseslovens $§ 67$ straffes disciplinært.

En opgørelse over ikendte disciplinærstraffe i fængsler for 2017 viser, at der samlet set blev idømt 21.746 disciplinærstraffe. Heraf var 3\% - eller cirka 653 sager - begrundet med overtrædelse af rygereglerne (Direktoratet for Kriminalforsorgen 2017: 34). Det skal bemærkes, at rygeloven først trådte i kraft pr. 1. april, hvorfor antallet ikke omfatter et helt kalenderår.

Ifølge fængslernes »normalreaktionsskema« følger det, at hvis der sker overtrædelse af et indendørs rygeforbud, eller hvis den indsatte findes i besiddelse af røgtobak, rygemedier og genstande til brug for fremstilling af cigaretter i eget eller andres opholdsrum, ikendes den indsatte i førstegangstilfælde en advarsel. Ved anden overtrædelse af rygereglerne ikendes der en bøde på $50 \mathrm{kr}$. Den tredje gang stiger bøden til 75 kr., og fjerde gang er bøden på 100 kr. + tre dages betinget strafcelle. Den femte gang straffes den indsatte disciplinært med tre til fem dages strafcelle (Kriminalforsorgen Syddanmark 2017). Strafcelle foregår i isolation uden fællesskab med personalet eller andre indsatte. Personalet har ikke mulighed for at fravige disse regler, selv om de måtte vurdere, at disciplinærstraf ikke er hensigtsmæssigt i det enkelte tilfælde. Af den kommenterede høringsoversigt henleder Justitsministeriet opmærksomheden på, at strafcelle kun kan anvendes for visse nærmere opregnede forhold eller forsøg herpå samt andre grove eller oftere gentagne forseelser, jf. straffuldbyrdelseslovens $\S 68$, stk. 1 og 2 (Justitsministeriet 2016b).

At det indendørs rygeforbud har påvirket omfanget af ikendte strafcelleanbringelser, fremgår af Kriminalforsorgens notat om de foreløbige erfaringer med det indendørs rygeforbud, hvori det anføres, at:

Der er matrikler, der i perioder oplever, at et stort antal disciplinærsager i forbindelse med overtrædelse af rygeforbuddet ligefrem giver kø til strafcelle. Foruden at blive taget $\mathrm{i}$ at ryge indendørs eller i at opbevare cigaretter og lightere på cellerne, er der disciplinærsager på grund af såkaldt »erstatningspåkrævende adfærd«, når de indsatte ødelægger elektriske apparater med det formål at kunne antænde cigaretter. (Direktoratet for Kriminalforsorgen 2019b:7).

Brugen af strafcelle er i øvrigt langt fra uproblematisk, da det er forskningsmæssigt dokumenteret, at isolation kan have en negativ påvirkning af indsattes mentale helbred og det anbefales at isolation bør kun bruges i helt exceptionelle tilfælde 
(Smith 2006, Shalev, 2008). Samtidig konstaterer Folketingets Ombudsmand i en nylig temarapport, at der er mangler i Kriminalforsorgens procedure for brug af isolationscelle. For eksempel har personalet ikke let adgang til en oversigt over, hvor mange dage den enkelte indsatte tidligere har været $\mathrm{i}$ isolation, og de kan dermed ikke tage hensyn til den kumulative effekt af isolationen (Folketingets Ombudsmand 2019:22). Derudover mangler der ensartede vejledninger for, hvordan de ansatte skal forebygge, observere og håndtere eventuelle psykiske skader (Folketingets Ombudsmand 2019:21).

I en kronik bragt i Information den 5. august 2019, forfattet af retsordfører for Enhedslisten Rosa Lund og tidligere fængselsinspektør Hans Jørgen Engbo, fremgår det, at den automatiske brug af disciplinærstraf, hvor der ikke forekommer en vurdering af nødvendigheden, er i klar strid med det almindelige forvaltningsretlige proportionalitetsprincip, som omfatter, at offentlige myndigheder ikke må anvende mere indgribende foranstaltninger, hvis mindre indgribende er tilstrækkelige. Desuden skal et indgreb som middel stå i rimeligt forhold til målet (Lund \& Engbo, 2019). Dette synspunkt er i overensstemmelse med retspraksis fra EMD, som ofte udtaler, at et indgreb skal være proportionalt - altså, at det ikke skal være mere indgribende end nødvendigt for at opnå målet (Gerards 2019:247).

Det skal bemærkes, at Kriminalforsorgen vurderer, at rygeforbuddet har forbedret det fysiske indeklima - når der lige ses bort fra de steder, der i forvejen havde en effektiv udluftning, og som altså ikke var generet af røgen, før forbuddet blev indført. Samtidig oplever enkelte betjente stadig at blive udsat for passiv rygning, når de følger de rygende indsatte på gårdture (Direktoratet for Kriminalforsorgen 2019b:1). I øvrigt konstaterer Kriminalforsorgen selv, at rygeforbuddet ikke har sat en stopper for de indsattes trang til at ryge, idet personalet opdager overtrædelser af forbuddet på samtlige matrikler (Op.cit:7). I et lukket fængsel har Arbejdstilsynet endvidere konstateret, at »risikoen for ildspåsættelse i fængslet er høj, da hændelserne er forårsaget af, at indsatte har kortsluttet køleskabe og tv-apparater, når de har skullet antænde cigaretter i cellerne, da de ikke må have lightere.« (Arbejdstilsynet, 2019:2).

Dertil kommer, at adskillige fængsler ikke tilbyder hjælp til rygestop, såsom udlevering af nikotinsubstitutionspræparater og egentlige rygestopkurser (Direktoratet for Kriminalforsorgen 2019b:6).

Når man sammenholder den automatiserede tildeling af disciplinærstraf med den manglende indsats $\mathrm{i} ø v$ rigt for at bringe rygning til ophør, er det svært at se, at forbuddet med den tilhørende sanktion skulle være proportionalt. Dette skyldes især to forhold: For det første var problemet med passiv rygning i hvert fald i visse fængsler allerede løst ved bedre ventilation, før forbuddet trådte i kraft. Der 
findes altså tilsyneladende langt mindre indgribende midler, der kunne have været brugt, i stedet for et egentligt forbud med dertilhørende brug af isolationscelle for gentagne overtrædelser. Valget af forbud er altså ikke proportionalt. For det andet fastslår FN's minimumsstandarder for behandling af indsatte, at længden af isolation skal være så kortvarig som mulig, og at isolation kun skal bruges i exceptionelle tilfælde, hvilket Ombudsmanden også påpegede i sin rapport (Folketingets Ombudsmand 2019:22). At man har valgt at bruge en straf beregnet på exceptionelle tilfælde til noget, der må betragtes som en ganske forudsigelig og nærmest rutinemæssig overtrædelse, kan ikke siges at være proportional. Altså må det vurderes, at både forbud og straf er uproportionale i forhold til det mål, som man ønskede at opnå, nemlig renere luft.

Endelig skal det vurderes, om rygeforbuddet udgør forskelsbehandling, idet det specifikt er rettet imod indsatte.

\section{Lige behandling af statens borgere}

Det er en menneskeretlig standard, at personer, der fuldbyrder fængselsstraf, skal bevare de samme rettigheder, som omfatter de øvrige borgere i samfundet (se også EMD Hirst v. UK og Florea v. Romania, gennemgået ovenfor). Derudover indeholder Den Europæiske Menneskerettighedskonventions artikel 14 et diskriminationsforbud. Staten må således ikke gøre forskel på borgerne, medmindre der er en god, faktuel grund hertil. Dette argument efterprøves oftest (og nemmest) ved at holde to sammenlignelige situationer op imod hinanden.

I Lov om røgfrie miljøer $\S 11$ fremgår det, at på plejehjem, døgninstitutioner m.v. kan den enkelte beboer selv beslutte, om der må ryges i det værelse, der fungerer som den pågældendes private hjem. I denne sammenhæng defineres »hjem«", som det værelse eller den bolig der tjener som den enkelte beboers private hjem. Vi har altså her et eksempel på, at arbejdspladser ikke altid er fuldstændig røgfrie, i en situation hvor arbejdspladsen omfatter private hjem. Hvis vi antager, som ovenfor diskuteret, at en celle kan defineres som et hjem, i hvert fald i de tilfælde, hvor de indsatte afsoner længere straffe, har vi altså her to direkte sammenlignelige situationer. I begge tilfælde opholder personalet sig i kortere eller længere tid på værelserne. I det ene tilfælde (plejehjem og døgninstitutioner) må beboerne gerne ryge på eget værelse. I det andet tilfælde (fængsler) må de indsatte ikke ryge på eget værelse.

Når rygning tillades $\mathrm{i}$ den ene situation, hvor personale opholder sig i borgerens hjem (plejehjem og døgninstitutioner), er det svært at se, at hensynet til personalet skulle kunne retfærdiggøre, at der ikke også må ryges i den anden situation (fængsler). Hensynet til beboernes egen sundhed må også antages at være det 
samme, idet rygning er skadeligt, uanset om man bor på en døgninstitution eller i et fængsel. I private hjem er man for at tilgodese personalet begyndt at installere luftrensere, der fjerner røgpartiklerne (Jørgensen \& Lange 2019). Der foreligger ingen oplysninger om, at en sådan løsning er forsøgt i de danske fængsler. Af et notat vedr. høring om det indendørs rygeforbud i Kriminalforsorgens institutioner fremgår det imidlertid, at enkelte fængsler allerede havde løst problemet med passiv rygning ved hjælp af ventilationsanlæg, inden rygeforbuddet trådte i kraft (Direktoratet for Kriminalforsorgen 2019b). En teknisk løsning på problemet kunne derfor muligvis være fundet, men er så vidt vides ikke blevet afprøvet.

Det er svært at se, hvad den store forskel på de to situationer skulle være, især når man ikke har prøvet at løse problemet teknisk i fængslerne, som man er begyndt at gøre i de private hjem. Derfor må konklusionen være, at der sandsynligvis er tale om diskrimination, jf. EMRK's artikel 14, sammenholdt med artikel 8. Hvorvidt EMD ville afsige en sådan dom, er dog lidt mere tvivlsomt, idet der ikke finde en fælles europæisk eller international konsensus på denne problemstilling, og domstolen derfor kunne finde, at spørgsmålet ligger inden for den enkelte stats skønsmargin, lige som tilfældet har været med passiv rygning.

\section{Diskussion og konklusion}

Den 1. april 2017 blev der indført et indendørs rygeforbud i Kriminalforsorgens institutioner, hvor det også blev muligt at straffe indsatte disciplinært for overtrædelse af rygelovens regler. Lovændringen er på den ene side anerkendelsesværdig, fordi rygeforbuddet skaber et bedre indendørs klima i fængsler, og ophold i røgfrie miljøer er at foretrække af helbredsmæssige årsager. På den anden side foranlediger det indendørs rygeforbud problemer, fordi indsatte er frihedsberøvede og i mange tilfælde låst inde $\mathrm{i}$ mange af døgnets timer, hvorfor de ikke selv kan bestemme, hvornår de kan ryge. Der er hverken international eller europæisk konsensus på området, om end trenden går i retning af stadig flere rygeforbud i fængsler såvel som i det omgivende samfund.

En begrundelse for et rygeforbud i danske fængsler og arresthuse er, at personalet og andre indsatte ikke skal udsættes for passiv rygning. Det forholder sig imidlertid sådan, at personalet til enhver tid kan kræve, at den indsatte lufter ud i sin celle, forud for at personalet skal varetage arbejdsopgaver i dennes celle, hvorfor problemet med at blive udsat for passiv rygning kan løses på denne måde. Samtidig er problemet tilsyneladende ikke forsøgt løst gennem bedre ventilation og/eller luftrensere, selvom løsningerne ser ud til at virke. Derudover afsoner indsatte i danske fængsler som hovedregel i enkeltmandsceller, hvorfor medindsatte ikke udsættes for passiv rygning. 
I det omgivende samfund bestemmer borgeren selv, om der må ryges tobak i eget hjem. Selv om indsatte med lange fængselsstraffe som udgangspunkt betragter deres celle som deres hjem og deres bolig, har de ikke ret til at bestemme over egen celle, idet staten kan intervenere i boligen, såfremt det forfølger et anerkendelsesværdigt formål, herunder at beskytte andres sundhed. Et rygeforbud i egen celle beskytter imidlertid ikke først og fremmest andres sundhed, men mest af alt den pågældende indsattes sundhed. Det klinger dog lidt hult, at man vil beskytte den indsatte rygers egen sundhed, når der ikke er tilstrækkelige tilbud om hjælp til afvænning, herunder tilbud om rygestopkurser til indsatte (Direktoratet for Kriminalforsorgen, 2019b).

Derudover kan den indsatte som nævnt risikere at være låst inde i sin celle $\mathrm{i}$ op til 23 timer i døgnet, og i det tidsrum har den indsatte i sagens natur ikke mulighed for at ryge.

Hvis indsatte overtræder rygeregler, kan de i yderste konsekvens blive straffet med isolation i op til fem dage. Man kan i høj grad sætte spørgsmålstegn ved, om det er proportionalt at straffe med isolation for overtrædelse af rygeregler.

Sammenlagt må det altså konkluderes, at retten til aktiv rygning i fængsler nok ikke er en krænkelse af EMRK's artikel 3, men muligvis af artikel 8. Dette skyldes, at forbuddet - og især den valgte form for sanktion - ikke kan siges at være proportionalt eller nødvendigt, idet det tidligere regelsæt opfyldte stort set samme formål, men med langt mindre indgribende midler. Samtidig har man ikke valgt at tilbyde hjælp til afvænning, hvilket signalerer, at man kun har tænkt på de ansattes rettigheder, ikke de indsatte selv. Dette er i direkte modstrid med EMD's udtalelser om, at staten skal være særlig påpasselig i forhold til indsattes rettigheder, da staten så at sige har overtaget ansvaret for dem ved at idømme dem en fængselsstraf. Derudover er der sandsynligvis tale om diskrimination af de indsatte, jf. EMRK artikel 14, sammenholdt med artikel 8, idet beboere på plejehjem og døgninstitutioner gerne må ryge på eget værelse, selv om personale også færdes dér i arbejdsøjemed.

\section{Litteratur}

Blume, P. (2016). Retssystemet og juridisk metode. Jurist og Økonomforbundets Forlag. København.

Butler, T.; R. Richmond; J. Belcher; K. Wilhelm; A. Wodak (2007). Should smoking be banned in prisons? Tobacco Control 291, 291-293. https://doi.org/10.1136/tc.2007.021600. PMid:17897977 PMCid:PMC2598573

Clausen, S. \& Bien, N. (2018). Vold og trusler mod Kriminalforsorgens personale Udviklingen fra 2007-2017. Direktoratet for kriminalforsorgen. København. 
Direktoratet for Kriminalforsorgen. Koncernledelsessekretariatet (2019). Tal fra kriminalforsorgen - april 2019. Tilgængelig via https://www.kriminalforsorgen.dk/wp-content/uploads/ 2019/04/tal-fra-kriminalforsorgen-april-2019-1.pdf

Direktoratet for Kriminalforsorgen (2019b). Notat vedr. høring om det indendørs rygeforbud i Kriminalforsorgens institutioner, 9. marts 2019, sagsnummer 17-40-0172. Direktoratet for Kriminalforsorgen. København.

Direktoratet for Kriminalforsorgen (2017). Statistik. Direktoratet for Kriminalforsorgen. København.

Djachenko, A.; W.S. John; C. Mitchell (2016). Smoking cessation in smoke-free prisons: a grounded theory study. International Journal of Prisoner Health, Vol. 12 (4) 270-279. https://doi.org/10.1108/IJPH-06-2016-0019. PMid:27921634

Enggist, S.; L. Møller; G. Galea; C. Udesen (2014). Prisons and Health. World Health Organization. Regional Office for Europe. Copenhagen. Denmark.

Folketingets Ombudsmand (2019). Temarapport 2018 Udelukkelse fra fællesskabet i kriminalforsorgens institutioner. 23. august 2019. Tilgået d. 11. september 2019 på http://www.om budsmanden.dk/ombudsmandensarbejde/ombudsmandens_sagstyper/tilsyn/temaer/temarap port_udelukkelse_fra_faellesskabet/

Gerards, J (2019). General Principles of the European Convention on Human Rights. Cambridge University Press. Cambridge. United Kingdom. https://doi.org/10.1017/9781108652926

Jørgensen, M. \& Lange, M.F. (2019). Kamp mod tobaksrøg i private hjem: Sosu'er skal skånes for lugtgener. 29. august 2019. Tilgået d. 11. september 2019 på https://www.dr.dk/nyheder/ regionale/midtvest/kamp-mod-tobaksroeg-i-private-hjem-sosuer-skal-skaanes-lugtgener

Kauffman, R.M.; A.K. Ferketich, D.M. Murray; P.E. Bellair, \& M.E. Wewers (2011). Tobacco Use by Male Prisoners Under an Indoor Smoking Ban. Nicotine \& Tobacco Research, Volume 13 (6), 449-456. https://doi.org/10.1093/ntr/ntr024. PMid:21447838 PMCid:PMC3103718

Lindstad, J.M. (2016). Brugerundersøgelsen 2015. Holdninger og vurderinger blandt indsatte i fængsler og arresthuse - Samlet rapport. Koncern Resocialisering. Analyse og Evaluering. Direktoratet for Kriminalforsorgen. København. Danmark.

Maes, E. (2019). Legal implications of smoking (bans) in English prisons. Legal Studies, 39, 321-338. https://doi.org/10.1017/1st.2018.46.

Nielsen, N. (2011). Retten til et hjem - Ejendomsret, privatliv og forsørgelse. Jurist- og Økonomforbundets forlag. København.

OHRN [The Offender Health Research Network] (2014). Smoking in Prisons in England and Wales: Considerations for Policy Change. Tilgået den 6. august 2019 via http://www.ohrn. nhs.uk/OHRNResearch/Smoking.pdf

Puljevic, C.; R. Coomber; S.A., Kinner; D., Andrade; C., Mitchell; A., White; S.L., Cresswell; J., Bowman (2018). Drug and Alcohol Review, 37, 912-921. https://doi.org/10.1111/dar. 12848. PMid:30051520

Shalev, S. (2008). A Sourcebook on Solitary Confinement. London: Mannheim Centre for Criminology, London School of Economics.

Smith, P.S. (2006). The Effects of Solitary Confinement on Prison Inmates: A Brief History and Review of the Literature. Crime and Justice 441, 444-450. https://doi.org/10.1086/500626

Spaulding, A.C.; G.D. Eldridge, C.E. Chico, N. Morisseau, A. Drobeniuc, R. Fils-Aime, C. Day, R. Hopkins, X.J.J. Chen, K.A. Dolan (2018). Smoking in Correctional Settings Worldwide: 
Prevalence, Bans, and Interventions. Epidemiologic Reviews, Vol. 40, 82-95. https://doi.org/ 10.1093/epirev/mxy005. PMid:29746635 PMCid:PMC5982806

\section{Danske retskilder}

Bekendtgørelse nr. 1610 af 18. december 2018 om indsattes adgang til at medtage, besidde og råde over egne genstande m.v. og penge i kriminalforsorgens institutioner (genstandsbekendtgørelsen).

Betænkning afgivet af Retsudvalget den 8. december 2016. Forslag til lov om ændring af lov om røgfri miljøer og lov om fuldbyrdelse af straf m.v. (Udvidelse af rygeforbuddet i kriminalforsorgens institutioner m.v.).

Justitsministeriet (2016a). Besvarelse af spørgsmål nr. 390 (Alm. del), som Folketingets Retsudvalg har stillet til justitsministeren den 10. marts 2016. Sagsnummer 2016-0030-4293. Tilgået den 6. august 2019 via https://www.ft.dk/samling/20151/almdel/reu/spm/390/svar/ 1313369/1617176.pdf

Justitsministeriet (2016b). Retsudvalget 2016-17. L43. Bilag 1. Kommenteret høringsoversigt. Forslag til lov om ændring af lov om røgfri miljøer og lov om fuldbyrdelse af straf m.v. (Udvidelse af rygeforbuddet i kriminalforsorgens institutioner m.v.). Sagsnummer 20161902-0362. Tilgået den 6. august 2019 via https://www.ft.dk/samling/20161/lovforslag/ L43/bilag/1/1680287.pdf

Justitsministeriet (2016c). Retsudvalget 2016-17. L43. Bilag til bilag 1. Tilgået den 6. august 2019 via https://www.ft.dk/samling/20161/lovforslag/L43/bilag/1/1680288.pdf

Kriminalforsorgen Syddanmark (2017). Normalreaktionsskema Søbysøgård Fængsel, Lukket afdeling $\mathrm{H}$.

Lovbekendtgørelse nr. 1284 af 14 november 2018 (Retsplejeloven)

Lovbekendtgørelse nr. 1491 af 13. december 2017 om fuldbyrdelse af straf mv.

Lov nr. 1726 af 27. december 2016 om ændring af lov om røgfri miljøer og lov om fuldbyrdelse af straf m.v. (Udvidelse af rygeforbuddet i kriminalforsorgens institutioner m.v.)

Lov nr. 641 af 8 juni 2016 om ændring af lov om fuldbyrdelse af straf m.v., straffeloven og retsplejeloven (Styrket indsats mod mobiltelefoner i fængsler m.v.)

Lov nr. 512 af 6 juni 2007 om røgfri miljøer (rygeloven)

Internationale retskilder og domme fra EMD

Council of Europe (1950). European Convention on Human Rights. Tilgængelig via https://www.echr.coe.int/Documents/Convention_ENG.pdf

European Court of Human Rights [EMD] (2004). Application no. 36150/03: Aparicio Benito v. Spain. Absence of no smoking area for detainees. Tilgængelig via https://hudoc.echr.coe.int/ eng\#\{"itemid":["001-78183"]\} og https://hudoc.echr.coe.int/eng\#\{"itemid":["001-44906"]\}.

European Court of Human Rights [EMD] (2005). Application no. 74025/01: Hirst v. the United Kingdom (No. 2). There is no question, therefore, that a prisoner forfeits his Convention rights merely because of his status as a person detained following conviction. Tilgængelig via https://hudoc.echr.coe.int/eng\#\{\%22itemid\%22:[\%22001-70442\%22]\}

European Court of Human Rights [EMD] (2005). Application no. 35207/03: Ostrovar v. Moldova. Tilgængelig via https:/www.tobaccocontrollaws.org/litigation/decisions/md20060215-ostrovar-v.-moldova 
European Court of Human Rights [EMD] (2008). Application no. 36244/02: Stoine Hristov v. Bulgaria

European Court of Human Rights [EMD] (2010). Application no. 37186/03: Florea v. Romania. Applicants subjection to passive smoking in detention was in breach of the convention.

European Court of Human Rights [EMD] (2011). Application no. 38427/05: Elefteriadis v. Romania. The authorities failed to safeguard the health of the applicant, who had been exposed to fellow prisoners' tobacco smoke.

European Court of Human Rights [EMD] (2014). Application no. 64682/12: Vasilescu v Belgium. The Court recommends that Belgium envisage adopting general measures guaranteeing prisoners adequate conditions of detention.

Heilbrigðis- og tryggingamálaráðuneyti, [Sundhedsministeriet] (2007). Reglugerð um takmarkanir á tóbaksreykingum, [Forordning om begrænsninger for tobaksrygning] Nr. 326/2007. Island. Tilgængelig via https://www.reglugerd.is/reglugerdir/allar/nr/326-2007

Kriminalvårdens [kriminalforsorgen] föreskrifter och allmänna råd om häkte (2011). KVFS 2011:2. Kriminalvården. Sverige. Tilgængelig via https://www.kriminalvarden.se/global assets/om_oss/lagar/fark-hakte-konsoliderad-2014_4pdf

Lov om vern mot tobakksskader (tobakksskadeloven) med senere ændringer. LOV-1973-03-0914. Helse- og omsorgsdepartementet. Norge. Tilgængelig via https://lovdata.no/dokument/ NL/lov/1973-03-09-14

United Nations (2015). United Nations Standard Minimum Rules for the Treatment of Prisoners 70/175 (Mandela-reglerne). Tilgængelig via https:/www.un.org/en/events/mandeladay/ mandela_rules.shtml

Vankien asuminen ja perushuolto (19/004/2010) [forordning om indsattes grundlæggende behandling og indkvartering]. Finland. Tilgængelig via https://www.rikosseuraamus.fi/fi/ index/seuraamukset/saannokset/maarayksetjaohjeet/vankienasuminenjaperushuolto 1900420 10.html

World Health Organization (2003). WHA56/2003/REC/1. Geneva. Schweiz. Tilgængelig via https://apps.who.int/iris/bitstream/handle/10665/259836/WHA56-2003-REC1-eng.pdf? sequence $=1 \&$ isAllowed $=\mathrm{y}$

\section{Pressemeddelelser, artikler fra fagblade, avisartikler}

Fantoft, S. (2011). Røyken fanger. Astma Allergi 5. Tilgængelig via https://www.naaf.no/ globalassets/x-gamle-bilder/documents/1.-astmaallergi/astma5_side58.pdf

Folketingets Ombudsmand (2019). Ombudsmanden undersøger brugen af strafcelle i fængsler og arrester. Nyhed den 18. marts 2019. Tilgængelig via https:/www.ombudsmanden.dk/ find/nyheder/alle/ombudsmanden_undersoeger_brugen_af_strafcelle_i_faengsler_og_arrester/

Fængselsforbundet $(2018,19$. november). De indsatte låses inde i længere tid. Tilgængelig via https://faengselsforbundet.dk/de-indsatte-laases-inde-i-laengere-tid/

Kyed, M. (2019, 19. marts). Flere indsatte og færre fængselsbetjente lægger pres på fængselsvæsnet. Tilgængelig via https://www.information.dk/indland/2019/03/flere-indsatte-faerrefaengselsbetjente-laegger-pres-paa-faengselsvaesnet

Lund, R. \& H.J. Engbo (2019). Overdreven brug af isolationsfængsling skyldes populistisk leflen for retsfølelsen. Information den 5. august 2019. 
Uutiset (2018). Sörkan vankilasta tänään savuton - muut vankilat seuraavat perässä. Tilgås via https://yle.fi/uutiset/3-10331337

VT (2019). Förslag: Totalt rökstopp på häkten och anstalter. Tilgås via https://www.vt.se/ nyheter/forslag-totalt-rokstopp-pa-hakten-och-anstalter-om6203418.aspx

Westfall, Kristian (2015). Arbejdsmiljørepræsentanter: syv ud af ti fængselsbetjente plages af passiv rygning. Fængselsforbundet, 10. 